\title{
A study of first-year students' adaptation difficulties as the basis to promote their personal development in university education
}

\author{
Aleksandr A. Orlov ${ }^{a}$, Svetlana V. Pazukhina ${ }^{b^{*}}$, \\ Aleksey V. Yakushin ${ }^{c}$, Tat'yana M. Ponomareva ${ }^{a}$ \\ ${ }^{a}$ Chair of Pedagogy, Tula State Lev Tolstoy Pedagogical University, Tula, Russia \\ ${ }^{b}$ Department of Psychology, Tula State Lev Tolstoy Pedagogical University, Tula, Russia \\ ${ }^{c}$ Department of Mathematics, Physics and IT Technologies, Tula State Lev Tolstoy \\ Pedagogical University, Tula, Russia \\ “Corresponding author. E-mail: pazuhina@mail.ru
}

Background. The relevance of the paper is determined by the study of types, structure of adaptive difficulties and their impact on the student's personal development in the process of professionalization in the university.

Objective. To examine the psychological characteristics of difficulties that arise in the process of students' adaptation to university instruction.

Design. The authors divide the difficulty in adaptation into four categories: motivational, communicational, cognitive, and regulatory. For each category, the authors offer pedagogical technologies that promote the personal development of students on the basis of their prevailing difficulties.

Results. Motivational difficulties are related to poor cognitive motivation, poor motivation to master a profession. Communication difficulties are attributed by the authors to poor communication skills. Cognitive difficulties are defined by insufficient general learning skills and a poor capacity for reflection and self-esteem. The source of regulatory difficulties is a lack of self-organization skills and poor self-control.

Conclusion. Correlation analysis confirmed that there are significant connections between, on the one hand, students' adaptability to the educational process and to their study group, and on the other, the investigated parameters that show their motivational, communicative, cognitive, and regulatory difficulties. Using cluster analysis of the empirical data, the authors identified four main student subgroups with different graphic profiles reflecting their personal difficulties in adaptation to university education; their psychological characteristics are given. Analysis of these difficulties has allowed the authors to offer an optimal psychological and educational strategy for the interactions of each of the subgroups, to optimize their personal development in the educational process.

Keywords: adaptation; personal development; adaptational difficulties 


\section{Introduction}

The adaptation of a modern student to instruction at the university entails a number of problems that require timely detection and acknowledgement in the process of training for a career, in particular the promotion of personal development.

Any adaptation involves transformation of human relationships with the environment, changes in attitude to the content and organization of one's activities (Andreeva, 2008). The essence of human adaptation is optimal adjustment to the demands of the environment. If the subject moves to another environment (object adaptation), with unfamiliar living conditions, and faces changes in the environment, this undermines stability; it creates a discrepancy between the characteristics of the subject and the object, which can lead to functional disorders and a loss of the integrity of the systemic relations between them. An adaptive situation arises when the system or its individual elements restore equilibrium. This situation is typical for all kinds of human adaptation, which is considered in modern psychology as an active, purposeful process of conflict resolution originating from interaction with the new natural or social environment (Nalchajyan, 2010). The release mechanism for adaptation is a change of environment, as a result of which habitual behavioral norms become less effective, which in turn gives rise to the need to overcome the difficulties encountered (Nagorkina, 2006). We share the opinion of authors who believe that the concept of man as an adapting creature is limited and must be superseded by analysis of actions and selfdevelopment (e.g., Alekhin, 2008; Badanina, 2009; Vasiliev, 2000). An important result of adaptation is the subject's personal development. Our study examines adaptation in several aspects: adaptation of students to educational activities and adaptation to their study group; both cases are accompanied by changes in the personal traits and relationships of a first-year student (Orlov, Isaev, Fedotenkov, \& Turevsky, 2007).

Successful adaptation facilitates the students' rapid adjustment to requirements and learning styles that are new to them, building positive relationships with teachers and fellow students, the actualization of self-realization motives in creative work, socially significant work, sports, and the Students' Scientific Research Activity (SSRA); it becomes a fertile ground for personal and professional self-development. Various aspects of the process of students' adaptation to university education have been studied by many domestic and foreign scientists. Thus L. Reisberg (2000) paid particular attention to student stress. L.A. Kolmogorova (2008) identified the features of adaptation and motivation of first-year students' learning for various types of professional self-determination. The specific nature of the social and psychological adaptation of students is treated by B.G. Meshcheryakov and G.I. Sobolev (2010), O.N. Dolgova (2014), and A.A. Kuz'mishkin (2014). G.Yu. Avdienko (2007) showed the influence of psychological help as psychological counseling for students, in the initial period of their instruction, on the success of their adaptation to the university environment. L.A. Antipova (2008) described pedagogical technologies that promote successful adaptation of students to university education. The value of specific technologies and academic subjects in facilitating the successful adaptation of first-year students was shown by A.A. Karabanov, A.N. Pogorelko, and E.A. Il'in (2010) and A.Yu. Lakhtin (2014). Yu.I. Tolstykh (2011) developed 
criteria for evaluating the adaptation of first-year university students. A.V. Panikhina (2015) considered the adaptation of first-year students to their university education.

In the present work, we have focused on the specific personal difficulties that occur during first-year students' adaptation to instruction in a higher educational institution. This research was important to us for scientific substantiation and the further development of students' individual educational pathways, to make it possible to optimize their personal development. Our objectives are the following: to diagnose types and psychological features of personal adaptation difficulties; to identify the dependence between various types of difficulties; to determine the negative impact of the difficulties upon first-year students' adaptation to the educational activity and to the educational group; and to define strategies for interaction with the students to overcome the difficulties identified.

For theoretical understanding of the problem, we have highlighted a number of personal difficulties that prevent successful adaptation, which we have classified into four groups: motivational, communicational, cognitive, and regulatory.

The following indicators of motivational difficulties have been considered: low level of cognitive motivation, lack of interest in learning particular disciplines, undeveloped motives associated with mastery of a profession, predominance of external over internal motives, and ambivalence of motives. Indicators of communicative difficulties are: low level of communicative skills, inability to communicate with peers, problematic interaction with teachers, poorly developed organizational skills, inability to work in a group (team), excessively blunt communication, and lack of flexibility. We relate cognitive difficulties to insufficient general learning skills necessary for successful university studies, and to a poorly developed capacity for self-assessment and reflection. Regulatory difficulties are judged by: underdeveloped self-organization, poor self-control, and lack of independence.

\section{Methods}

The study was based at Tula State Lev Tolstoy Pedagogical University. Two study groups composed of 46 undergraduates in the Department of Mathematics, Physics, and Computer Science participated in a pilot experiment.

The following complementary techniques were used for the diagnosis of personal adaptational difficulties by dedicated criteria and indicators: T.D. Dubovitskaya's and A.V. Krylova's methods of studying university students' adaptation; T.I. Ilyina's method of studying motivation in university studies; B.A. Fedorshina's method of studying communicational and organizational skills (COS); V.I. Morosanova's method "style of behavioral self-regulation"; O.V. Kalashnikova's method to determine pedagogical reflection formation. All tests meet the required quality indicators for a psychodiagnostic toolkit: validity, reliability, accuracy, and a standardized view.

The empirical results for each of these methods are summarized in a single matrix. For several scales, all values had been previously converted into a uniform 10 -point system. They were then subjected to quantitative analysis using mathematical statistics. 


\section{Results}

By cluster analysis, we have allocated four main subgroups (clusters) of students in the test sample, with various graphic profiles according to the parameters studied. All profiles were constructed based on the use of average values by the relevant indicators of scales in a subgroup (cluster).

Each scale corresponds to one of the indicators:

scale 1 - motive to acquire knowledge

scale 2 - motive for professional mastery

scale 3 - motive to obtain a degree

scale 4 - adaptability to the study group

scale 5 - adaptability to learning activity

scale 6 - communication skills

scale 7 - organizational skills

scale 8 - planning

scale 9 - modelling

scale 10 - programming (i.e., it aims to diagnose individual development of conscious programming by a person of their own actions)

scale 11 - evaluation

scale 12 - flexibility

scale 13 - independence

scale 14 - overall self-regulation

scale 15 - level of reflection.

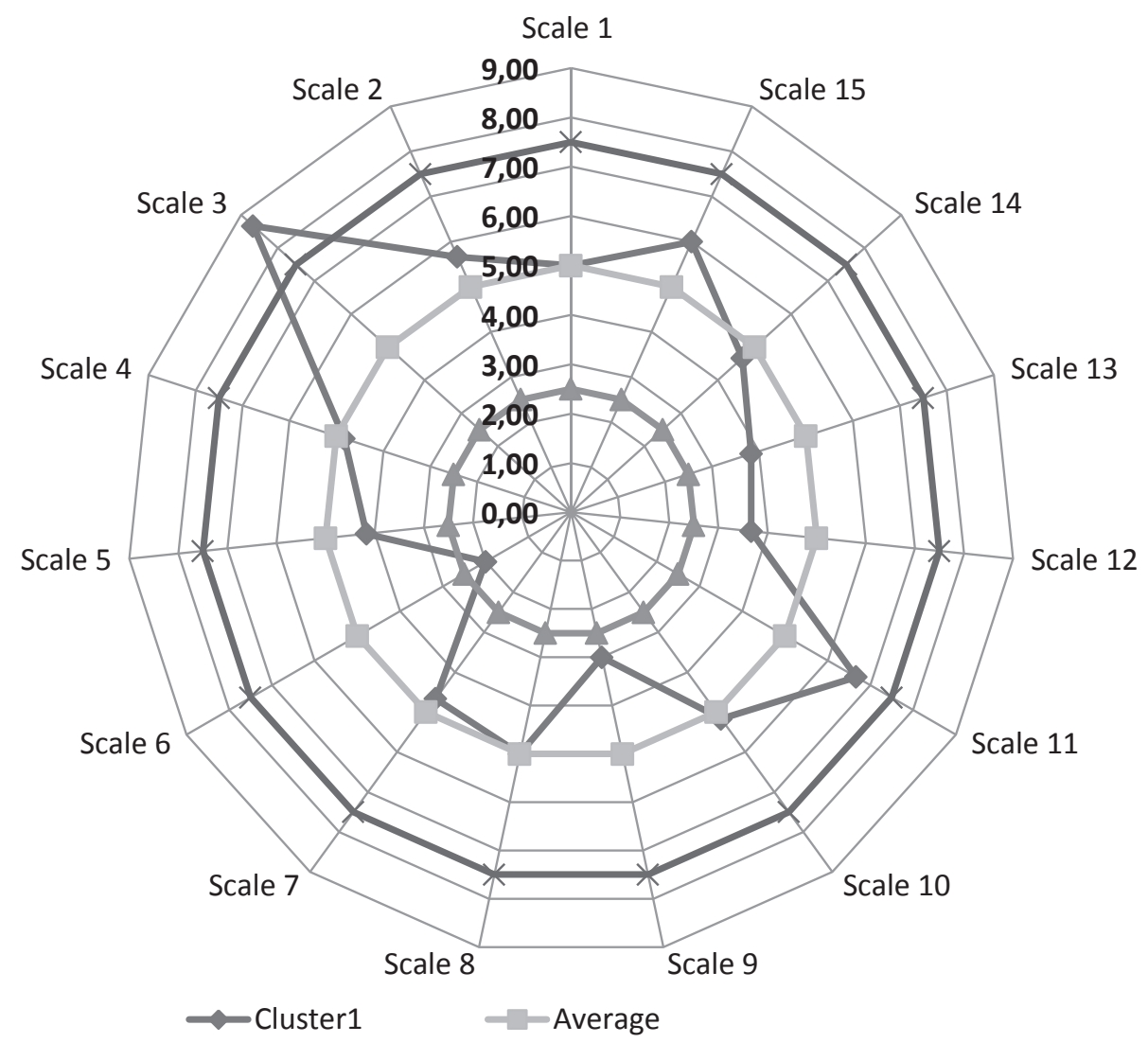

Figure 1. Generalized graphic profile of the first subgroup of students 
Motivational difficulties are correlated with indicators on scales 1,2 , and 3. Communication difficulties have been judged by scales $4,6,7$, and 12 . Low results on scales $5,8,9$, and 10 showed cognitive difficulties. Low indicators on scales 11 , 13,14 , and 15 indicted regulatory difficulties.

Describing students in the first subgroup (cluster), it should be noted that their generic graphic profile has a curved, uneven, asymmetrical, and angular view. The profile has both below-average indicators and indicators exceeding the boundaries that were based on average values (Figure 1).

The highest scores in the first subgroup of students are found on scale 3 (motivation to obtain a degree); scale 11 (ability to evaluate results); and slightly below those, on scale 15 (level of reflection). The findings suggest that for these students, conscious motivations external to the university's educational process predominate, associated with the desire to acquire a degree through formal mastery of knowledge. The predominance of motives on the third scale indicates a formal approach to the students' choice of profession, and dissatisfaction with it. As a rule, these students are studying in an institution which they are able to enter with their scores on the Unified State Examination (USE). At the same time they assess their capabilities appropriately (as shown by their relatively high scores on scales 11 and 15); they know that their level is below average and do not seek high scores and a high position in their group.

Scales 6 (communication skills), 9 (modelling), 12 (flexibility), and 13 (independence) rank low in the first profile. The lowest indicators are found on these scales in the subgroup. The data show that students in this cluster have serious communication difficulties (poor communication skills, undeveloped skill of communication with peers, potential problems in interaction with faculty). First-year students with low indicators on the scale of flexibility in a dynamic, rapidly changing environment feel insecure in their adaptation to university, find it hard to adjust to changes, to the change of environment and lifestyle. They are unable to respond appropriately to a situation, to plan their own activities and behavior quickly and promptly; to develop a program of action; to evaluate a misalignment of their results with the purpose of the activities; and to make adjustments in a timely manner. As a result, failures of self-regulation and, as a consequence, failure in learning activities will inevitably occur with these students.

Poor development of the "modelling" skill is seen in students with low indicators on scale 9. This leads to an inappropriate assessment of significant internal states and external circumstances arising in the learning process, which is shown in fantasizing, and may be accompanied by rapid changes in relation to the development of the situation and the consequences of one's own actions. Such students often have difficulty determining the goals of and programs for their own actions that are appropriate to the current situation; they do not always notice changes in circumstances, often leading to failures in learning activities.

Low levels of independence on scale 13 indicate respondents' dependence on the opinions and evaluations of others. Such students cannot develop plans and programs for their own actions; they often uncritically follow someone else's advice. If there is no outside help, they will inevitably have problems in learning.

These difficulties of a personal nature will inevitably result in the low scores for the students' adaptation to educational activity that can be seen in their graphic profiles (values below average on scale 5). 
The students of the first subgroup had mainly average scores on the other indicators.

Thus, first-year students in the first cluster are characterized by distinct motivational, communicative, cognitive, and regulatory difficulties. As a rule, they are quiet and dependent people, C-students, usually loners, who are not particularly popular in their study group.

In order to promote the personal development of the students, it is advisable to use a strategy of psychological and educational assistance in pedagogical interaction with them. This means the maximum individualization of learning activities that will generate intrinsic motivation, the necessary communication skills, and abilities to overcome the problems that impede the process of cognition and to produce qualities that ensure a normal level of self-regulation of these first-year students.

The second cluster is characterized by a quite asymmetrical, angular histogram image, showing the disproportion of several of the scores (Figure 2). However, unlike in the first subgroup, in this cluster all scores, even on the lower scales, are in the above-average range.

The highest values for the second subgroup are on scales 3 (motive to obtain a degree), 4 (adaptability to the study group), and 12 (flexibility in behavior and communication). Consequently, both these students and those in the first subgroup have predominantly external conscious motivation associated with the desire to obtain a degree in the formal acquisition of knowledge, and to look for shortcuts during exams, tests, etc. As a rule, such students do not care so much

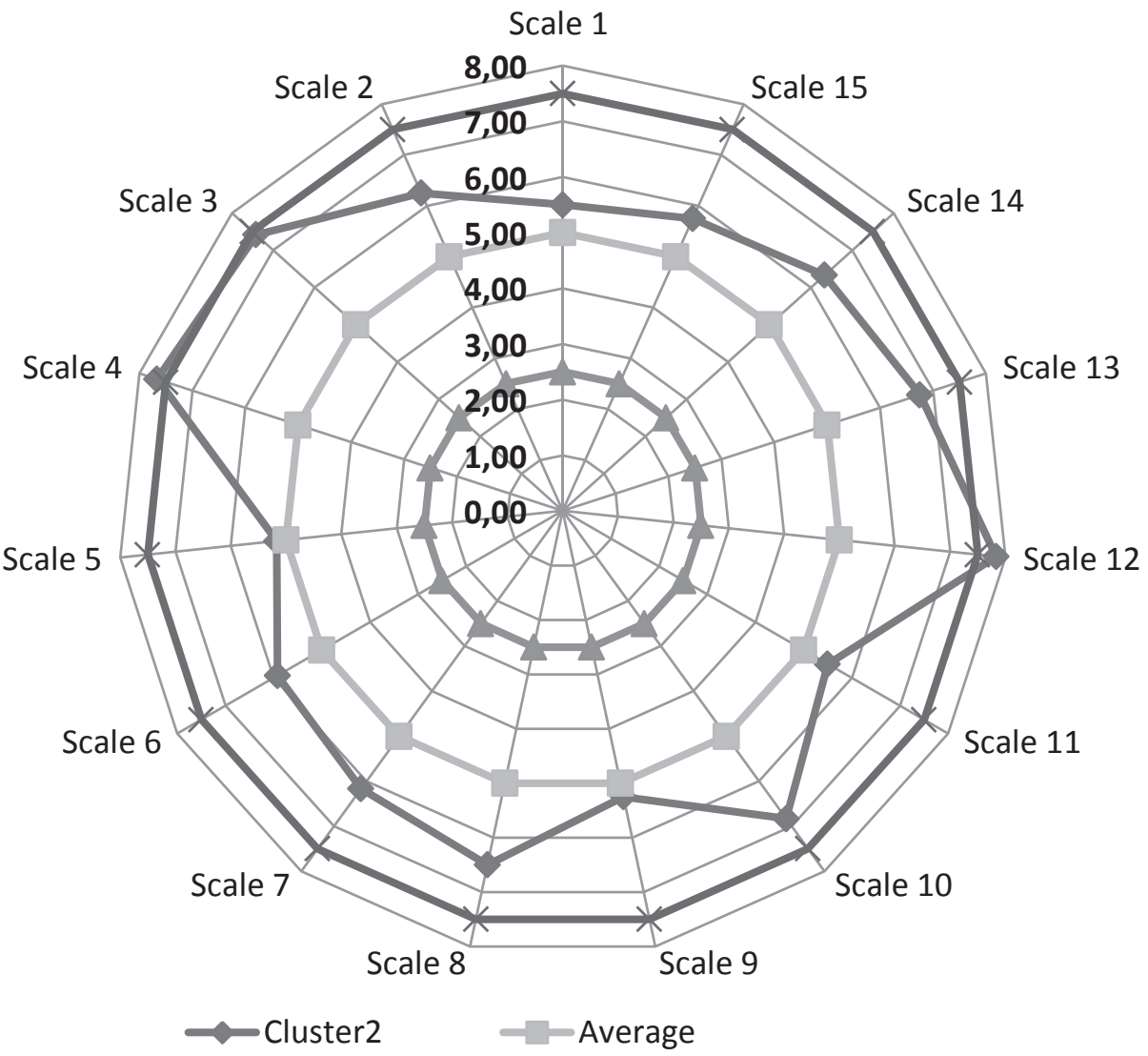

Figure 2. Generalized graphic profile of the second subgroup of students 
where they study, as long as they get a diploma in higher education. They do not need knowledge itself, but just want a mark in a gradebook, usually without any special effort, using the qualities they already have: flexibility of behavior in various communicative situations, a good relationship with the group, and all kinds of assistance from acquaintances. If necessary, such students interact with other students in the group, others taking the course, faculty, or familiar teachers who can prompt, give a write-off, negotiate, etc.; they do not hesitate to ask for help and quietly use cheat sheets written by fellow students; they post requests on the Internet to upload the lectures of a particular teacher, ask who takes exams and tests with which teachers and how they are, etc.; they can easily change their point of view to the opposite depending on the situation, and tend to flexibly manipulate information and people.

Relatively high points in the second subgroup of students are also recorded on scales 10 (programming) and 13 (independence). The ability to program is manifested in the individual development of ways of consciously thinking through one's actions and behaviors to achieve one's goals. The programs are independently developed. If there is a discrepancy between the results and the objectives, the program of action is corrected until an acceptable result is achieved. All this is done with a well-developed sense of independence, which is a weak point of the first group of students.

High indicators on the scale of independence demonstrate autonomy in organizing the students' activities, their ability to plan and conduct operations by themselves, to work towards advanced targets, to monitor the progress of implementation, to analyze and evaluate both the intermediate and final results of the activity.

As already mentioned, there are no low indicators in the second subgroup of students. All values are either at the middle levels or above average. Nevertheless, analysis of three relatively low scales in this subgroup is of interest.

The lowest scores of the students in the second cluster are on scale 5 (adaptability to learning activity), 9 (modelling), and 11 (evaluation). The histogram graphically shows the relationship between lack of the necessary motivation to learn and low adaptability to the instructional activity, which, in our opinion, is logical.

The ability to model reflects the individual development of ideas about significant external and internal conditions, the degree of their awareness, specification, and relevance. These students are not always able to identify the significant conditions for achieving their goals, either in the current situation or in the more distant future, as is manifested in a number of cases in the incompatibility of the action programs with their activity plans, as well as in the disparity between the results and the established goals.

Finally, not very high average scores on the "evaluation" scale point to the fact that in this subgroup of students, assessment of oneself and the results of one's activity is not sufficiently developed and not always appropriate.

Thus, in the second subgroup, only motivational difficulties are diagnosed as clearly defined. To improve the effectiveness of the students' personal development, in our opinion, a strategy of psychological and pedagogical support will be optimal. The essence of pedagogical interaction between teachers and students is to promote students' individual initiatives, to enhance their participation in research, and to include them in social and pedagogical design work. It is also necessary to take into 


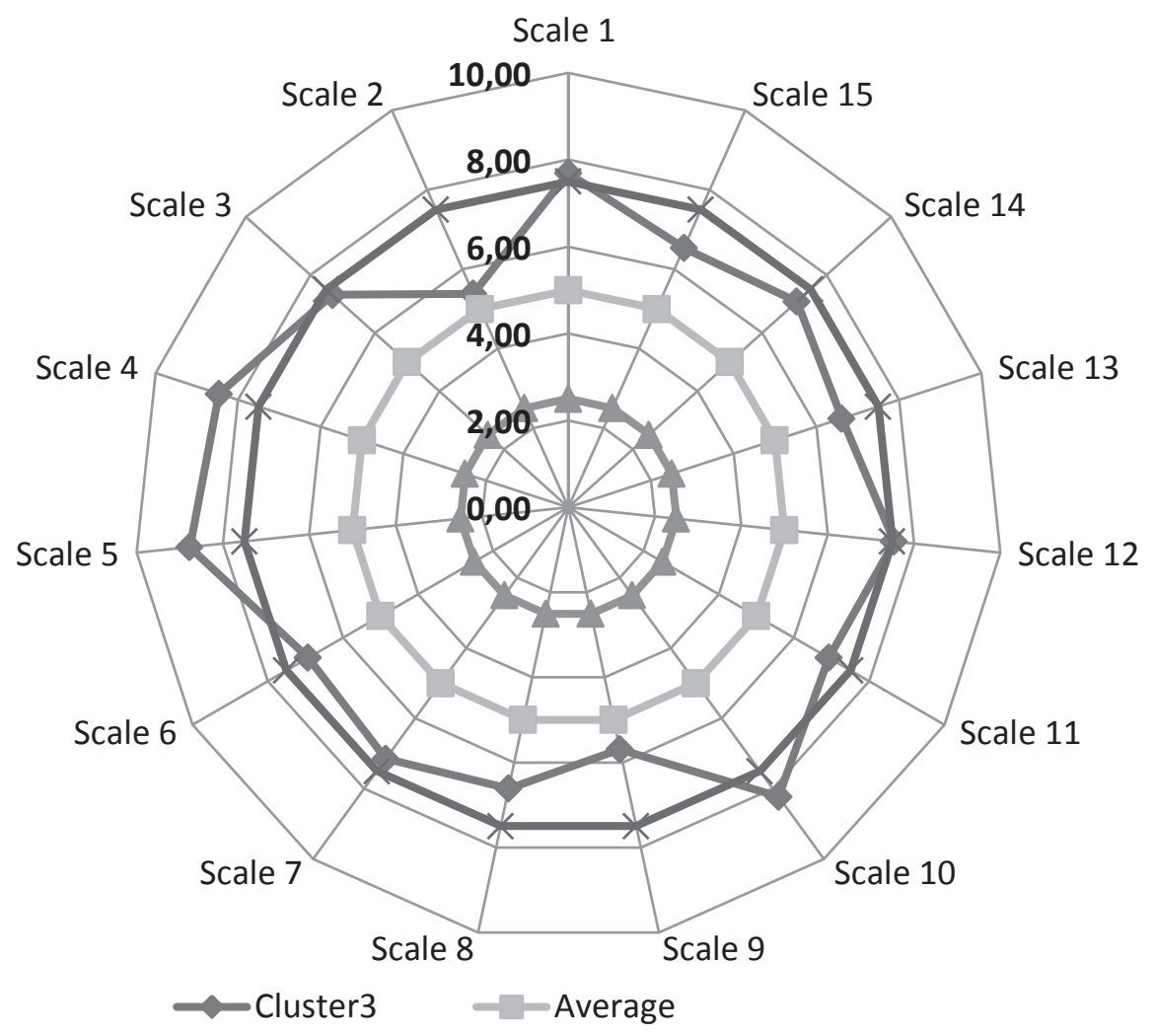

Figure 3. Generalized graphic profile of the third subgroup of students

account their independence, flexibility of behavior, not always appropriate self-esteem, and to strive for the development of internal motivation for educational and professional activity.

A generalized profile of the students referred to the third subgroup (cluster) is characterized by predominance of values above average. Their graphic profile has uneven edges and is not particularly symmetrical (Figure 3). There are several peak vertices which clearly stand out above the others, and there are two scales that are clearly lower than the other averages.

The highest values of the third subgroup are on scales 1 (motive to acquire knowledge), 4 (adaptability to the study group), 5 (adaptability to learning activity), and 10 (programming). High values on the first scale point to the prevalence of internal conscious cognitive motivation, expressed in striving for knowledge, interest in learning the academic subjects, and intellectual curiosity. Developed cognitive motivation conforms to good adaptability to the educational activity, which is manifested in the fact that students easily master academic subjects, successfully fulfil learning tasks in a timely manner, can ask the teacher for help if necessary, freely express their thoughts in seminars, and can express their personalities and abilities in the classroom.

Students of the third subgroup, according to the average values reflected in the chart, are well adapted not only to learning activity, but also to the study group. They have a genuine friendly relationship with fellow students developed in the course of instruction at the university; a cohesive team is formed; a sense of mutual responsibility and unity in value-orientation emerges. These students feel comfort- 
able in the group; it is easy for them to find a common language with classmates and to adhere to the group norms and regulations. If necessary, they can apply to group mates for help, be proactive and take the lead in the group. Fellow students also accept and support the views and interests of such students.

High indicators on the "programming" scale show that the students have developed a need to think over the way they act to achieve the established goals, how well the programs they have worked out are detailed and deployed. Programs are developed by them independently, changing flexibly in new circumstances and sustainable in a situation of disturbance.

The average values in the cluster are recorded on scales 2 (motive of professional mastery) and 9 (modelling). We can assume that these students are interested in studying at the university; they like to learn new disciplines, but they have not quite decided on their profession and see no connection between the acquired knowledge and their future professional activities. This is reflected in their modelling of important conditions for achieving their goals, both in the current situation and in the more distant future, which is manifested in the insufficient conformity of their action programs to the plans for their future professional activity, and a not very clear correlation of their results with the established goals.

Thus, the third subgroup has no obviously expressed difficulties of a personal nature that arise in the process of adaptation to instruction at the university. On the contrary, they can be described as almost perfect first-year students, who are ready and able to learn in groups, in particular with teamwork and joint activities. They need help in the formation of proper professional motivation, to reveal as much as possible their capabilities for future professional activity, to build (to model) relevant plans for the future: "I'm part of the profession." When designing pedagogical

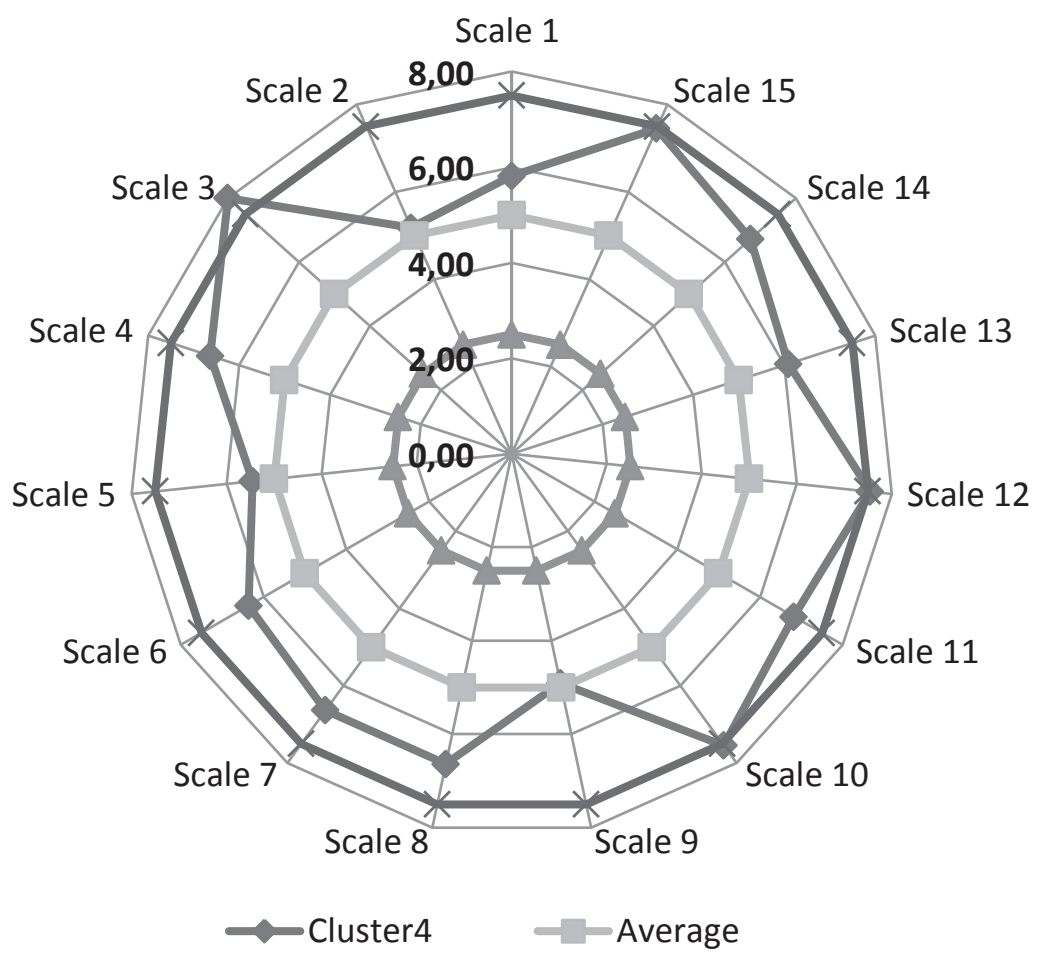

Figure 4. A generalized graphic profile of the fourth subgroup of students 
interaction with these students in order to optimize their personal development, in our view, a strategy of psychological and pedagogical support through coaching will be suitable, whereby the teacher teaches students how to solve educational and professional problems.

The generalized graphic profile of students whom we have assigned to the fourth subgroup in cluster analysis has an asymmetrical view with protruding edges and several relatively low indicators (Figure 4). Most values on this scale are above average.

Peak vertices in the fourth cluster are fixed on scales 3 (motive to obtain a degree), 10 (programming), 12 (flexibility), and 15 (reflection). Thus, in this subgroup, there is dominance of external conscious formal motivation associated with the desire to get a diploma. At the same time, cognitive motivation (scale 1) has values higher than average.

The fourth subgroup is characterized by students' individual development of conscious programming of their actions. They tend to think carefully about how their own actions can contribute to the achievement of the established goals. Typically, these students develop detailed, comprehensive programs on their own; they are able to adjust them, to change flexibly according to the circumstances, and to defend their expediency in a challenging situation of interference.

Students in this cluster demonstrate rather high regulatory flexibility, i.e., the ability to revise, to make a correction to the system of self-regulation under changing internal and external conditions. If unforeseen circumstances occur, such students easily revise the plans and programs for implementation and behavior; they are able to quickly assess changes in significant conditions and revise their plan of action. If there is a discrepancy between the results and the accepted goal, they assess the fact of the mismatch in a timely manner and make the appropriate correction. Regulatory flexibility allows them to respond appropriately to rapidly changing events and to successfully solve assigned tasks, even in a situation of risk.

In contrast to the other subgroups of students, representatives of the fourth cluster have high indicators on the scale of "reflection", which is manifested in the ability to analyze themselves, their mental states, personal knowledge, the results of their own activity, their rethinking, and so on.

In the fourth subgroup, relatively low values in the middle zone are found on scales 2 (motive of professional mastery) and 9 (modelling). This indicates insufficient awareness about the choice of a future career or low satisfaction with their chosen profession. Doubts about the correctness of a professional choice affect the modelling of significant conditions to achieve the goals by such students, both in the current situation, and in the future perspective that is manifested by insufficient conformity of their programs of action with the plans for their future professional activity, and in a not entirely clear correlation of the results with the established goals.

In general, the students from the fourth cluster do not have any significant adaptation difficulties from our list of personal difficulties. When designing pedagogical interaction with them, it is advisable to use a strategy of one-on-one psychological and pedagogical counselling, with an emphasis on self-evaluation activities because of the relatively high level of development of reflexive abilities in these stu- 
dents. Such pedagogical interactions, in our opinion, will stimulate most effectively the further personal development of students in this group.

We have conducted a correlation analysis of the data obtained during this work, which has shown a number of significant relationships between the adaptability of first-year students to the learning activities and the educational group, and to the specified indicators of personal adaptational difficulties.

We have shown that adaptability to learning activity is positively correlated with the motivation to acquire knowledge (the Pearson's $\mathrm{r}$ linear correlation coefficient between these indices was 0.35 , which is significant for the study sample at $\mathrm{p}<0.05)$, communicative abilities $(\mathrm{r}=0.46, \mathrm{p}<0.01)$, organizational skills $(\mathrm{r}=0.52$, $\mathrm{p}<0.01)$, planning $(\mathrm{r}=0.32, \mathrm{p}<0.05)$, modelling $(\mathrm{r}=0.39, \mathrm{p} \leq 0.01)$, programming $(\mathrm{r}=0.33, \mathrm{p}<0.05)$, flexibility $(\mathrm{r}=0.39, \mathrm{p} \leq 0.01)$, independence $(\mathrm{r}=0.3, \mathrm{p} \leq 0.05)$ and general level of self-regulation $(\mathrm{r}=0.52, \mathrm{p}<0.01)$. It was found that cognitive motivation is positively correlated with programming of oneself and one's future professional activity $(\mathrm{r}=0.41, \mathrm{p}<0.01)$; reflection also had a positive correlation with "programming" $(\mathrm{r}=0.52, \mathrm{p}<0.01)$.

Adaptability to the study group had positive correlations with communication skills $(\mathrm{r}=0.5, \mathrm{p}<0.01)$ and organizational skills of first year students $(\mathrm{r}=0.55, \mathrm{p}<0.01)$, adaptability to learning activity $(\mathrm{r}=0.44, \mathrm{p}<0.01)$, overall self-regulation $(\mathrm{r}=0.39$, $\mathrm{p} \leq 0.01)$ as well as flexibility $(\mathrm{r}=0.5, \mathrm{p}<0.01)$.

The strongest positive correlations were recorded between communication skills and flexibility (Pearson's $r$ linear correlation coefficient between these indices was 0.74 , which is significant for the study sample at $\mathrm{p}<0.01)$, general level of self-regulation and programming $(\mathrm{r}=0.7, \mathrm{p}<0.01)$.

A significant negative correlation was established between the formal activities external to the educational and professional activities at the university, motive to obtain a degree and modelling one's future in the profession $(\mathrm{r}=-0.35, \mathrm{p}<0.05)$.

These correlations have helped to adjust strategies for interaction with students who have various kinds of personal difficulties that impede their productive adaptation to the educational process of higher education.

\section{Conclusion}

In the course of this pilot study, we have identified a number of difficulties of a personal nature (motivational, communicative, cognitive, and regulatory) preventing successful adaptation of first-year students to instruction at a higher educational institution.

Correlation analysis has confirmed the presence of significant interrelations between students' adaptability to the instructional activity and study group, and the indicators we studied showed the students' motivational, communicative, cognitive, and regulatory difficulties.

Using cluster analysis of the data, we identified four main subgroups of students with different graphic profiles reflecting the type of personal difficulties arising in the process of their adaptation to instruction at university; their psychological characteristics are given.

Analysis of the specific adaptational difficulties allows us to offer an optimal psychological and educational strategy for the organization of pedagogical interac- 
tion with students for each of the selected subgroups; its use to the greatest degree possible will contribute to their personal development at a higher educational institution.

In the future, we plan to expand the sampling and to conduct a full-scale pilot study to identify the most productive periods of students' personal development in the educational process at the university and the impact of these on the students' professional development.

\section{Acknowledgement}

Funding: This article was prepared under state task No. 2014/389, SRW (Scientific and Research Work), No. 2193.

\section{References}

Alekhin, I.V. (2008). Izmeneniye usloviy podgotovki studentov vysshikh uchebnykh zavedeniy $i$ $i k h$ adaptatsii $v$ usloviyakh transformatsii rossiyskogo obshchestva [Changing conditions of preparation of students at higher educational institutions and their adaptation to transformations of Russian society]. Vestnik Bashkirskogo universiteta, 2, 366-368. http://bulletinbsu.com

Andreeva, G.M. (2008). Sotsial'naya psikhologiya [Social Psychology], $5^{\text {th }}$ ed. Moscow: Aspekt Press

Antipova, L.A. (2008). Pedagogicheskiye tekhnologii uspeshnoy adaptatsii lichnosti studenta $v$ protsesse obucheniya $v$ vuze [Pedagogical technologies of successful adaptation of the student's personality in the learning process at the university]. Kazanskiy pedagogicheskiy zhurnal, 2, 52-56. http://kpj.ippporao.ru/node/11

Avdiyenko, G.Yu. (2007). Vliyaniye meropriyatiy psikhologicheskoy pomoshchi studentam $v$ nachal'nyy period obucheniya na uspeshnost' adaptatsii k obrazovatel'noy srede vuza [Impact of psychological assistance to students at the initial stage of instruction for successful adaptation to the university educational environment]. Vestnik psikhoterapii, 24, 8-14. http:// arcerm.ru/vestnik-psihot.html

Badanina, L.P. (2009). Analiz sovremennykh podkhodov k organizatsii psikhologo-pedagogicheskogo soprovozhdeniya studentov na etape adaptatsii $k$ vuzu [Analysis of modern approaches to psychological and pedagogical support of students at the stage of adaptation to the university]. IZVESTIA: Herzen University Journal of Humanities and Sciences, 83, 99-108. https://www.herzen.spb.ru/main/nauka/1297772316

Dolgova, O.N. (2014). Sotsial'no-psikhologicheskaya adaptatsiya studentov. Profobrazovaniye, 15 avgusta [Social and psychological adaptation of students. Vocational education, August 15]. http://проф-обр.pф/blog/2014-08-15-282.

Karabanov, A.A., Pogorelko, A.N., \& Il'in, Ye.A. (2010). Ispol'zovaniye informatsionnykh tekhnologiy $v$ protsesse adaptatsii studentov mladshikh kursov [Use of information technologies in the process of adaptation of junior students]. Izvestiya Instituta inzhenernoy phiziki, 15, 21-23. http://izvestiya.iifrf.ru

Kolmogorova, L.A. (2008). Osobennosti motivatsii ucheniya i adaptatsii studentov-pervokursnikov s razlichnymi tipami professional'nogo samoopredeleniya [Features of learning motivation and adaptation of first-year students with various types of professional self-determination]. Mir nauki, kul'tury, obrazovaniya, 4, 100-103. http://amnko.ru/index.php/russian/aboutus/ 
Kuz'mishkin, A.A. (2014). Adaptatsiya studentov pervogo kursa v vuze [Adaptation of first-year students at the university]. Molodoy uchenyy, 3, 933-935. http://moluch.ru

Lakhtin, A.Yu. (2014). Teoreticheskiye osnovy problemy adaptatsii studentov $k$ obucheniyu $v$ vuze sredstvami fizicheskoy kul'tury [Theoretical basis of the problem of students' adaptation to university instruction by means of physical training]. Biisk, Russia: FGBOU VPO Altayskiy gosudarstvennyy tekhnicheskiy universitet im. I.I. Polzunova (AltGTU).

Meshcheryakov, B.G., Sobolev, G.I. (2010). Operatsionalizatsiya sotsial'no-psikhologicheskoy adaptatsii studentov [Operationalization of the social and psychological adaptation of students]. Kul'turno-istoricheskaya psikhologiya, 1, 56-64. http://psyjournals.ru/kip/ doi: 10.17759/jmfp.2016050301

Nagorkina, O.V. (2006). Sotsial'no-psikhologicheskaya adaptatsiya studentov v vuze v usloviyakh razvitiya studencheskogo samoupravleniya [Social and psychological adaptation of students at university under conditions of the development of student self-government]. Samara, Russia: Samarskiy gosudarstvennyy pedagogicheskiy universitet. http://search.rsl.ru/ru/ record/01003273246

Nalchajyan, A.A. (2010). Psikhicheskaya adaptatsiya: mekhanizmy i strategii [Psychological adaptation: mechanisms and strategies]. Moscow: Eksmo.

Orlov, A.A.; Isayev, Ye.I.; Fedotenko, I.L., \& Turevskiy, I.M. (2007, October 24). Dinamika lichnostnogo i professional'nogo rosta studenta pedvuza [Dynamics of the personal and professional growth of the student at a higher pedagogical educational institution]. Minsk: Belorusskaya tsifrovaya biblioteka LIBRARY.BY. http://library.by/portalus/modules/shkola/readme.php? archive $=1196815145 \&$ id $=1193230689 \&$ start_from $=\&$ subaction $=$ showfull\&ucat $=$

Panikhina, A.V. (2015). Otsenka adaptatsii studentov-pervokursnikov k obucheniyu v vuze [Evaluation of first-year students' adaptation to university instruction]. "Open Lesson" festival of pedagogical ideas. http://festival.1september.ru/articles/513384/.

Pazukhina, S.V. (2014). Refleksiya kak osnova samootsenochnoy deyatel'nosti studentov pri kompetentnostnom podkhode $k$ obrazovaniyu [Reflection as a basis for self-assessment activity of students in the competence approach to education]. Acmeology, 1-2, 176-177. http:// akmeology.ru

Reisberg, L. (2000, January 28). Student stress is rising. Especially among women. The Chronicle of Higher Education. 49-52. http://www.chronicle.com

Tolstykh, Yu.I. (2011). Kriterii otsenki uspeshnosti adaptatsii studentov-pervokursnikov v vuze [Criteria for assessing the success of first-year students' adaptation at the university]. Izvestiya vysshikh uchebnykh zavedeniy. Povolzhskiy region, 4 (20), 137-142. http://izvuz.pnzgu.ru

Vasilyeva, S.V. (2000). Adaptatsiya studentov $k$ vuzam s razlichnymi usloviyami obucheniya. Psikhologo-pedagogicheskiye problemy razvitiya lichnosti v sovremennykh usloviyakh: psikhologiya i pedagogika $v$ obshchestvennoy praktike [Adaptation of students to universities with different conditions for instruction. Psychological and pedagogical problems of personal development in modern conditions: psychology and pedagogy in social practice]. St. Petersburg: RGPU im. A.I. Gertsena. 